\title{
Media społecznościowe jako przestrzeń eksponowania ciała
}

\author{
DOI: 10.19195/2083-7763.8.6
}

Jednym z charakterystycznych dla ponowoczesności zjawisk jest przenikanie do sfery publicznej treści zarezerwowanych tradycyjnie dla sfery prywatnej czy wręcz intymnej, na przykład szczegółowe wyznania dotyczące uczuć, preferencji seksualnych itp. Widzialność dla wielu osób stanowi oznakę statusu społecznego i pozycji. Rację ma Bauman, pisząc:

Dziś napawa nas strachem nie tyle możliwość naruszenia lub pogwałcenia naszej prywatności, ile odwrotność tej sytuacji: zatrzaśnięcie dróg wyjścia ze świata prywatności, przekształcenie sfery prywatnej w miejsce odosobnienia, w jednoosobową celę więzienną czy ciemny loch ${ }^{1}$.

Taki ekshibicjonizm - rozumiany tu oczywiście nie jako parafilia, ale w wymiarze werbalnym oraz jako chęć upubliczniania zdjęć i filmów przedstawiających własne obnażone ciało - dotyczy zarówno celebrytów², jak i osób szerzej nieznanych. Wojciech Burszta nazwał to zjawisko - w odniesieniu do osób znanych (chociaż wiele refleksji dotyczy wszystkich jednostek) - regułą stringów umysłowych.

[...] string umysłowy bierze się stąd, że granica prywatności jest coraz cieńsza, staje się wręcz symboliczna, jak ów pasek materiału w plażowych majtasach. [...] string umysłowy to nie tylko zjawisko komunikacyjne, to także fenomen psychologiczny. Z jednej strony, mamy więc matryce kulturowych wzorów oznajmiania publiczności, jaki jest status danego idola [...]. Z drugiej

1 Z. Bauman, 44 listy ze świata plynnej nowoczesności, Kraków 2011, s. 51-52.

2 W tekście będę posługiwał się zamiennie określeniami „celebryta” (w klasycznym rozumieniu Boorstina) i „osoba powszechnie znana”, nie rozważając skądinąd interesujących podziałów na gwiazdy i celebrytów czy rozróżnień między celebrytą a ceWEBebrytą (zob. M. Janczewski, CeWEBryci - sława w sieci, Kraków 2011) i celebutantką (zob. O. Mazurek-Lipka, Sukces typu instant - tożsamość celebryty i celebutantki, „Kultura - Społeczeństwo - Edukacja” 2013, nr 2). 
strony, to przecież współczesne ikony wiedzą, iż muszą zgodzić się na obnażanie własnego życia (a raczej jego medialnej matrycy), bo od tego zależy ich status quo, albo - jak powiedzieliby socjologowie - taka jest ich społeczna rola i status ${ }^{3}$.

W procesie upubliczniania prywatności bardzo dużą rolę odgrywają media społecznościowe. Jak odnotowuje Marek Krajewski, ich rozwój

pociąga za sobą zagęszczanie sieci społecznych i coraz intensywniejsze kontakty międzyludzkie, [...] mamy do czynienia ze zjawiskiem, które można by nazwać publiczną intymnością. Istota tego fenomenu jest dostrzegalna w obrębie takich portali społecznościowych jak Facebook. Na pierwszy rzut oka służy on do kontaktów pomiędzy osobami, które się znają [...], ale sieci oplatające jednostkę bardzo szybko się rozrastają, co owocuje tym, iż jej bardzo prywatne odczucia, codzienne emocje, obrazy z jej domu, wakacji, pracy stają się publiczne, są komentowane, oceniane, dyskutowane przez użytkowników strony ${ }^{4}$.

Jednym z kluczowych elementów mediów społecznościowych jest fotografia. Celem niektórych z nich, na przykład Instagrama, jest zamieszczanie zdjęć przez użytkowników, ale w każdym z tych mediów osoby mające tam konto mogą dodawać zdjęcia ukazujące niekiedy silnie zseksualizowane ciało. Warto podkreślić, że choć na wielu portalach społecznościowych (np. na Facebooku) użytkownicy mogą ustawić swój profil tak, aby w pełni mogły go oglądać wyłącznie określone osoby, będące na liście kontaktów (w wielu przypadkach prywatność jest specyficznie rozumiana, gdyż liczba „znajomych” może być bardzo duża), często są one ostentacyjnie wystawiane na widok publiczny w celu uzyskania przez ich bohatera maksymalnej widzialności ${ }^{5}$.

Choć media społecznościowe posiadają regulacje zakazujące określonych prezentacji ciała (to zagadnienie zostanie omówione w dalszej części tekstu), są niezwykle ważną częścią zjawiska nazwanego przez Briana McNaira kulturą obnażania ${ }^{6}$.

Według Wielkiego stownika języka polskiego czasownik „eksponować” oznacza „wystawiać coś na pokaz" ${ }^{7}$. W niniejszym opracowaniu zostaną omówione różne aspekty eksponowania ciała w mediach społecznościowych (przede wszystkim Instagramie i Facebooku). Po pierwsze, przeanalizowane zostaną zasady zamieszczania zdjęć przedstawiających nagie i półnagie ciało oraz akcje społeczne kontestujące te regulaminy. Ważna będzie próba odpowiedzi na pytanie, czy te regulacje próbują ustalać kanon ciała godnego upublicznienia (inne skazując na niewidoczność), czy każda estetyka ciała jest traktowana jednakowo. Po drugie, zbadany

3 W. Burszta, String umysłowy i jego powaby, „Kultura Popularna” 2002, nr 2, s. 146.

${ }^{4} \mathrm{M}$. Krajewski, Intymność w przestrzeniach publicznych: powtórzenie, dyseminacja i rozproszenie, [w:] Formy zamieszkiwania. Publiczne i prywatne przestrzenie miasta, red. P. Wołyński, Poznań 2010, s. 31.

${ }^{5}$ Z. Melosik, Facebook i społeczne konstrukcje narcyzmu (o tożsamości zamkniętej w celi wizerunku), „Studia Edukacyjne” 2013, nr 26, s. 103.

6 Zob. B. McNair, Seks, demokratyzacja pożądania i media, czyli kultura obnażania, przeł. E. Klekot, Warszawa 2004, s. 5.

7 http://wsjp.pl/index.php?id_hasla=33625\&ind=0\&w_szukaj=eksponowa\%C4\%87+ (dostęp: 22.11.2016). 
zostanie poziom społecznej aprobaty odnośnie do upubliczniania zdjęć nacechowanych seksualnie. By osiągnąć ten cel, autor sięgnął po dwa zabiegi: przywołanie casusu Joanny Kuchty oraz poddanie analizie wypowiedzi zamieszczanych na wybranych portalach internetowych w Polsce, Anglii i Włoszech, dotyczących pokazywania przez celebrytów w mediach społecznościowych zdjęć czy filmów obnażonego ciała. Po trzecie, zaprezentowane zostaną przykłady eksponowania nagiego ciała niemającego seksualnych konotacji (albo mającego je w niewielkim stopniu).

Regulamin Instagrama zabrania publikowania określonych treści. Jak stanowi $\$ 2$ postanowień ogólnych:

Zabronione jest udostępnianie za pośrednictwem serwisu treści zawierających elementy przemocy, nagości, częściowej nagości, treści dyskryminacyjnych, niezgodnych z prawem, promujących nienawiść, treści pornograficznych oraz zdjęć i innych treści o podtekście seksualnym ${ }^{8}$.

Realizując tę regulację, administratorzy likwidują m.in. zdjęcia przedstawiające odsłonięte kobiece i męskie genitalia oraz nagie kobiece sutki. Są to skuteczne działania - fotografie przedstawiające „zakazane” obiekty są bardzo szybko kasowane.

Polityka mediów społecznościowych dotycząca prezentacji obnażonego ciała budzi wiele wątpliwości. Nagi kobiecy sutek w wielu wypadkach pozbawiony jest przecież całkowicie seksualnych konotacji (dobrą egzemplifikację stanowi karmienie dziecka piersią). Poza tym w serwisach tych można znaleźć ogromną liczbę zdjęć o silnym podtekście erotycznym (zamieszczanych głównie przez celebrytów, ale i nieznane powszechnie jednostki), ukazujących nagie (ale z zasłoniętymi sutkami) czy półnagie piersi, pozy jednoznacznie nacechowane seksualnie; nie są one usuwane przez administratorów. Warto w tym miejscu przywołać casus amerykańskiej modelki Chrissy Teigen. W 2015 roku zamieściła na Instagramie zdjęcie z wyeksponowanym biustem, wyraźnie było też widać sutek. To wystarczyło, by fotografia szybko zniknęła z serwisu. Teigen napisała na Twitterze. „Sutek został czasowo uciszony, ale jeszcze powróci. O tak, powróci"”. Po kilku godzinach zamieściła na Instagramie równie odważne zdjęcie co wcześniej, zakrywając jednak sutek lakierem do włosów. Nie zostało ono skasowane, choć ma - w mojej ocenie - identyczny podtekst erotyczny.

Przeciwko zakazowi pokazywania nagiego kobiecego sutka zorganizowano wiele kampanii, również społecznych. W 2012 roku w USA Lina Esco, aktorka, reżyserka i działaczka feministyczna, zainicjowała akcję „Free The Nipple” („Uwolnić sutek”) mającą na celu zmianę prawa zakazującego kobietom pokazywania się topless w niektórych amerykańskich stanach. Od 2014 roku kampania prowadzona jest też przeciwko omawianej polityce mediów społecznościowych. Akcję wsparło wielu celebrytów (m.in. Miley Cyrus). Esco słusznie zauważa:

${ }^{8}$ https://pl-pl.facebook.com/help/instagram/478745558852511 (dostęp: 21.11.2016).

9 "Sutek został czasowo uciszony, ale powróci. O tak, powróci”. Pomógł lakier do włosów, http://www. tvn24.pl/ciekawostki-michalki,5/zdjecie-z-sutkiem-chrissy-teigen-zniknelo-z-instagrama,556417. html (dostęp: 26.11.2016). 
„Jest mnóstwo facebookowych stron ociekających seksem i odkrytym ciałem, ale Facebook ich nie cenzuruje, bo sutki są zasłonięte" ${ }^{10}$. Modelka Anja Rubik, jedna z powszechnie znanych osób popierających tę kampanię, porusza szerszy problem dotyczący prezentacji ciała w mediach:

W Ameryce możesz pokazać wulgarne zdjęcia kobiet na okładkach magazynów dla mężczyzn i wszystko jest ok. [...] Ale jeśli pokażesz damski sutek w bardzo piękny i zmysłowy sposób w magazynie mody, ludzie są oburzeni. Dla mnie to zabawne. Każdy ma sutki ${ }^{11}$.

W 2016 roku działaczki niemieckiego oddziału „Różowych Wstążek” („Pink Ribbon”), organizacji wspierającej od lat kobiety cierpiące na raka piersi, stworzyły kampanię społeczną „Check it before it’s removed” („Sprawdź to, zanim zostanie usunięte"). W jej ramach kobiety pozują z obnażoną piersią (i sutkiem) - akcja ma na celu ostrzeganie kobiet przed chorobą nowotworową piersi i zachęcać je do regularnego badania, gdyż niewykryty odpowiednio wcześniej nowotwór piersi grozi ich usunięciem. Kampania ma też drugie dno, nawiązując do polityki Facebooka i Instagrama: „zobacz to zdjęcie, zanim zostanie usunięte”12. Początkowo serwisy usuwały zdjęcia, ale w związku z ogromnym zainteresowaniem internautów akcją zaprzestano tego.

Przeciwko regulacjom dotyczącym cenzurowania zdjęć wymierzona jest także internetowa akcja One Finger Selfie Challenge, powstała w 2016 roku. To „wyzwanie" polega na zrobieniu selfie przed lustrem w taki sposób, by za pomocą jednego palca zasłonić piersi i krocze (mężczyźni mogą zasłonić tylko genitalia). Rozpowszechniła ją youtuberka Aimee Davinson, która tłumaczy, że „ten trend został zapoczątkowany przez komiks autorstwa japońskiej artystki anime Skyfreeedom. Na obrazku główna postać komiksu robi sobie właśnie zdjęcie w lustrze, zasłaniając się jednym palcem"13.

One Finger Selfie Challenge będzie niewątpliwie kolejną internetową efemerydą, ale stanowi też dowód na to, że istnieje wiele sposobów na ominięcie cenzurujących regulacji.

10 M. Gąsior, „Uwolnićsutek!”- amerykańska aktorka walczy z cenzurą nagiego ciała na Facebooku http://natemat.pl/88303, uwolnic-sutek-amerykanska-aktorka-walczy-z-cenzura-nagiego-ciala-na-facebooku (dostęp: 27.11.2016).

11 Absurdalne przepisy Instagrama zabraniaja pokazywania kobiecych sutków, http://kobieta. gazeta.pl/kobieta/1,107881,18315825,nipple.html (dostęp: 27.11.2016). To zagadnienie jest jeszcze szersze - trudno znaleźć logiczne uzasadnienie nierównomiernego traktowania przez normy administracyjno-prawne seksualności i przemocy w przemyśle filmowym. Prezentacja tej pierwszej obwarowana jest wieloma zakazami, podczas gdy w wielu filmach i serialach znajdują się bardzo mocne sceny przemocy.

12 Kampania przeciw nowotworowi piersi kpi z zasad nagości na Facebooku i Instagramie, http:// www.wirtualnemedia.pl/artykul/kampania-przeciw-nowotworowi-piersi-kpi-z-zasad-nagosci-na-facebooku-i-instagramie-wideo\# (dostęp: 29.11.2016).

13 Nowe wyzwanie: zasłoń się jednym palcem!, http://kobieta.interia.pl/zycie-i-styl/news-nowe-wyzwanie-zaslon-sie-jednym-palcem,nId,2315667 (dostęp: 17.12.2016). 
Z polityką zakazu prezentacji określonych zdjęć wiąże się także bardzo istotny problem: czy wobec omawianych zapisów każde ciało jest równe? Innymi słowy: czy każdy typ urody traktowany jest tak samo, czy jednak dochodzi do uprzywilejowania danej estetyki?

W 2014 roku Samm Newman, mająca nadwagę, zamieszczała na swoim profilu na Instagramie swoje zdjęcia, między innymi w bieliźnie. Administratorzy serwisu usunęli jej zdjęcia, informując, że są zbyt odważne. Następnie zlikwidowali jej konto. Newman mówiła: „Paradoksalnie otrzymałam wiele słów wsparcia od tych samych osób, które naśmiewały się z powodu mojej tuszy w podstawówce i liceum" ${ }^{14}$. Aleksandra Zawadzka ma rację, pisząc:

Dlaczego skasowano jej zdjęcia? Na pewno nie za to, że były zbyt rozebrane. Codziennie pojawiają się tam setki fotografii, na których widać skąpo ubrane dziewczyny. Hasztag bikini? Ponad osiem milionów zdjęć. Hasztag hot? Dwadzieścia pięć milionów. A tam biusty, pośladki w stringach, nawet sceny seksu ${ }^{15}$.

Zarządzający Instagramem wydali oficjalne oświadczenie, że konto Newman usunięto przypadkowo. Nie jest to jednak odosobniony przypadek. Identyczna sytuacja, również w 2014 roku, spotkała Meghan Tonjes — kobietę także reprezentującą typ urody „plus size”. Jej zdjęcia w bikini, choć nienacechowane w żaden sposób seksualnie, również zostały usunięte przez administratorów, tłumaczących później, że nastąpiło to omyłkowo.

W 2015 roku Instagram zablokował hasztag \#curvy (krągły, zaokrąglony), którym posługiwały się kobiety o bujniejszych kształtach. Administratorzy twierdzili, że pojawiał się on przy zdjęciach zbytnio eksponujących nagość. Użytkowniczki protestowały, tłumacząc to tym, że „w aplikacji wciąż dostępne są hasztagi takie jak \#hookers (prostytutki) czy \#fetishes (fetysze), a niewinne \#curvy zostało zakazane"16. Skarg i informacji w mediach było tak wiele, że hasztag został przywrócony (choć nie na dotychczasowych zasadach - zaczęto używać algorytmu mającego wyeliminować pornografię i nagość).

Przywołane przykłady wskazują, że polityka mediów społecznościowych dotycząca przedstawiania ciała częściowo odkrytego albo nagiego jest bardzo niekonsekwentna. Wiele zdjęć jednoznacznie nacechowanych seksualnie nie jest traktowanych jako naruszenie regulaminu, podczas gdy inne - ukazujące ciało w żaden sposób nierozerotyzowane bądź budzące skojarzenia seksualne w bardzo niewielkim stopniu - są uznawane na naruszenie regulaminu i likwidowane.

14 Usunięta $z$ Instagrama $z a$ „rozbierane” zdjęcia, http://kobieta.wp.pl/usunieta-z-instagrama-za-rozbierane-zdjecia-5982735142450305a (dostęp: 22.11.2016).

15 A. Zawadzka, Masz zbędne kilogramy albo boczki? Uważaj, bo jeszcze usuna ci konto na Instagramie, http://natemat.pl/110277, masz-zbedne-kilogramy-albo-boczki-uwazaj-bo-jeszcze-usuna-ci-konto-instagramie (dostęp: 22.11.2016).

${ }^{16}$ Blogerki plus size walcza $z$ Instagramem. Serwis zablokowat hasztag \#curvy, http://www.tvp. info/20921619/blogerki-plus-size-walcza-z-instagramem-serwis-zablokowal-hashtag-curvy (dostęp: 25.11.2016). 
Przywoływane casusy Newman, Tonjes i hasztagu \#curvy uzasadniają wątpliwość, czy badane serwisy nie uprzywilejowują określonego typu ciała.

$\mathrm{W}$ analizie zagadnienia eksponowania ciała $\mathrm{w}$ mediach społecznościowych interesujący jest także poziom społecznej akceptacji upubliczniania przez użytkowników tych serwisów zdjęć własnego rozerotyzowanego ciała. W tym kontekście ważne jest przywołanie postaci Joanny Kuchty - osoby, która popularność w 100\% zdobyła poprzez publikację zdjęć nacechowanych seksualnie. Ta dwudziestoletnia Polka, mieszkająca od kilku lat w Irlandii, zajmuje trzecie miejsce wśród najczęściej obserwowanych Polaków na Instagramie (ma ponad milion followersów ${ }^{17}$ ). Popularność zdobyła, publikując od lat zdjęcia o silnym podtekście erotycznym. „Specjalnością Polki są ujęcia z łóżka lub łazienki i ciasne kadry na pupę, fragment biustu czy rozchylone usta. Do rekwizytów zaliczają się przezroczyste bluzki, skórzane obroże oraz lizaki”"18. Na bluzkach nierzadko znajdują się napisy typu: „poliż mnie” albo „te cycuszki są sztuką”. Zdjęcia ukazujące nagi sutek były usuwane przez administratorów, Kuchta zaczęła zatem zasłaniać sutki naklejkami. Zseksualizowany wizerunek utrwalany na każdym zdjęciu dopełniony jest sferą werbalną. Jedną z fotografii podpisała: „Jeśli to zgłosicie, to znaczy, że boicie się własnej anatomii". W wywiadzie powiedziała zaś:

Bardzo się cieszę, że dziewczyny zaczynają poznawać swoją seksualność, a nie tylko dostosowywać się do męskiego spojrzenia. Podoba mi się, że ludzie coraz rzadziej rozmawiają o tym, co podoba mężczyznom się, a coraz częściej - o tym, że kobiety powinny dobrze czuć się w swoim ciele ${ }^{19}$.

Popularność Kuchty nie uszła uwadze różnym markom - współpracowała miedzy innymi z American Apparel (notabene słynącej z kontrowersyjnych reklam o bardzo silnym podtekście seksualnym).

By porównać, jak eksponowanie ciała w mediach społecznościowych postrzegają mieszkańcy różnych krajów europejskich, przeanalizowanych zostało ponad 1600 wypowiedzi zamieszczonych w 2016 roku na sześciu forach internetowych (dwóch polskich ${ }^{20}$, trzech włoskich ${ }^{21}$ i jednym angielskim ${ }^{22}$ ) pod artykułami na temat publikacji przez celebrytów na Instagramie zdjęć nacechowanych

17 https://napoleoncat.com/analytics/instagram (dostęp: 7.01.2017).

18 N. Kędra, Joanna Kuchta: ta 19-letnia Polka ma więcej fanów na Instagramie niż Anja Rubik! Modelka przyszłości? [FENOMEN], http://kobieta.gazeta.pl/follow/1,153346,18516294,joanna-kuchta-modelka-instagram.html (dostęp: 30.11.2016).

19 R. Krzemińska, Joanna Kuchta - insta, wirtualne życie i feminizm, http://loungemagazyn.pl/ insta-wirtualne-zycie-i-feminizm/ (dostęp: 3.12.2016).

${ }^{20} \mathrm{http}: / /$ plejada.pl/newsy/joanna-krupa-nago-na-instagramie-co-za-cialo/sqlpxe, http://facet. onet.pl/naga-joanna-krupa-na-instagramie-robi-wrazenie-18/khjsln (dostęp: 7.01.2017).

${ }^{21} \mathrm{http}: / /$ www.corriere.it/foto-gallery/spettacoli/16_giugno_11/belen-provoca-nuovo-nudo-integrale-instagram-6a4870a0-2fb6-11e6-99a1-699f8214af13.shtml; http://www.ilmessaggero.it/ societa/gossip/belen_foto_nuda_instagram-1788464.html (dostęp: 7.01.2017).

22 http://www.dailymail.co.uk/tvshowbiz/article-3781724/Mariah-Carey-poses-completelyNAKED-fans-Instagram-indulges-relaxing-bubble-bath.html (dostęp: 7.01.2017). 
seksualnie. Te państwa zostały wybrane, ponieważ ich społeczeństwa wykazują wiele odmienności kulturowych - interesujące było to, czy będą one widoczne $\mathrm{w}$ badanych postach. Nie jest to badanie socjologiczne sensu stricto, ale stanowi próbę określenia społecznej akceptacji obnażonego ciała w mediach społecznościowych w kilku krajach. Polskie fora dotyczyły zdjęć Joanny Krupy, włoskie - Belen Rodriguez, a angielskie - Mariah Carey. Liczba wypowiedzi Polaków i Anglików była podobna, znacznie mniej było postów Włochów. Autor zrezygnował z analizy statystycznej wpisów, ponieważ najistotniejsze wydaje się określenie tendencji w badanych wypowiedziach. Najwięcej aspektów upubliczniania zdjęć obnażonego ciała odnotowano na polskich portalach, dlatego tym wpisom poświęcone będzie najwięcej miejsca.

Na wszystkich forach przeważały głosy krytyczne wobec eksponowania przez celebrytów ciała na Instagramie. W Polsce i we Włoszech aprobujących wypowiedzi było ok. 45\%, w Anglii zaś zaledwie ok. 8\%. Istotne jest to, że wiele postów dotyczyło konkretnych zdjęć, będących tematem artykułu, a nie zjawiska upubliczniania fotografii nacechowanych seksualnie.

$\mathrm{Na}$ polskich forach internauci wiele razy wyrażali bardzo negatywne zdanie na temat zdobywania/utrzymywania popularności poprzez publikowanie zdjęć $z$ podtekstem erotycznym ${ }^{23}$.

MASAKRA, JAK TRZEBA MIEĆ DUŻE PARCIE NA SŁAWĘ ABY STANĄĆ NAGO I PRZYPOMINAĆ SIĘ, AŻ ŻAŁOSNE (jaro, plejada).

Pojawiały się także głosy, że wyłącznie atrakcyjny wygląd nie jest wartością:

Jeśli ktoś poza wyglądem, nie ma niczego więcej do pokazania, wrażenia robić po prostu nie może (ed, onet).

Upublicznianie nagich zdjęć spotkało się z wieloma bardzo negatywnymi określeniami, na przykład kobiety to robiące przyrównywano do prostytutek:

NIEKTÓRZY MAJA WYŁACZNIE ładne ciało, ale takich kobiet na świecie sa tysiące. Tylko jedne sie publicznie za kasę rozbieraja i inne nie. Kiedyś takie porównywane były z inna profesją. [...] (logika, plejada).

Trend ten nazywano też między innymi ekshibicjonizmem czy patologią. Pojawiały się także opinie poruszające wątki egzystencjalne:

Żyjemy w czasach kultu ciała i pieniądza. I co z tego, że ma takie walory? Nie jedna kobieta o której świat nie słyszał jest piękniejsza i zgrabniejsza niż niejedna „gwiazdka”. I tak każdy ususzy się jak śliwka więc czy warto przywiązywać do ciała tak wielką uwagę? (hhhj, plejada).

Wielu internautów miało jednak odmienne zdanie. Pozytywnie oceniając dane zdjęcie, pisali między innymi:

${ }^{23} \mathrm{~W}$ wypowiedziach została zachowana oryginalna pisownia, po wypowiedzi pojawia się nick autora i skrócona nazwa forum, z którego pochodzi. 
Piękne, idealnie proporcjonalne ciało! Przyjemnie popatrzeć. Jej walory intelektualne, czy inne zalety, które na pewno istnieją, nie mają tu nic do rzeczy. Oburzenie świętoszków jest o wiele bardziej godne pogardy, niż śmiałość modelki [...] (dilmar, onet).

W wielu wypowiedziach podkreślano, że zadaniem modelki jest eksponowanie ciała i nie ma w tym nic złego:

Może miała założyć burkę? W końcu jest modelką i jej praca właśnie na tym polega, że pokazuje „SWOJE PIĘKNE CIAŁO” (Goya, onet).

Pojawiały się również posty, w których autorzy zajmowali stanowisko aprobujące upublicznianie obnażonego ciała pod warunkiem, że jest ono atrakcyjne:

Gorsze jak ktoś nie ma czym epatować a to robi. Jednak Krupa MA co pokazać. Twarz, piersi, tyłek. Wszystko na odpowiednim poziomie - niezależnie ile z tego natury a ile skalpela czy fotoshopa. Niestety mnóstwo znanych osób lansuje się w śmiałych sesjach nie reprezentując sobą fizycznie za wiele. Nie żenuje mnie taka publiczna golizna pod warunkiem, że pani prezentuje należyty poziom urody (jon, plejada).

Niektórzy internauci z kolei akceptują fotografie nacechowane seksualnie, dopóki nie są ukazane genitalia:

Żadnych intymnych części ciała nie pokazała, więc o co tyle krzyku. Przecież to jest modelka i pracuje ciałem, i to do póki jest ono ładne. Chyba nie liczy nikt na to że zarabia kopiąc motyką [...] (gość, plejada)

Pojawiały się ponadto posty na temat korelacji religia-nagość:

Uwaga katolicy, Bóg Was też stworzył nagich, a nie oskarżacie go (Heniek, onet).

Ciekawe że najbardziej wstydzą się swego stwórcy ci najbardziej wierzący (Ryszard, plejada).

We wpisach na włoskich forach (tłumaczenie - S.S.) przeważały głosy wyrażające znudzenie permanentnym szukaniem przez niektórych celebrytów popularności poprzez publikację rozbieranych zdjęć:

George Bernard Shaw powiedział: Piękno, po trzech dniach jest tak nudne jak cnoty (Lettore_1848095, corriere).

Część internautów krytykowała zjawisko eksponowania ciała przez kobiety będące matkami:

Ale świat jest pełen pięknych kobiet, więc niech stara się być bardziej skromna i pamięta, że jest matką, więc powinna unikać sytuacji niedopasowanych do rodzicielstwa!!! (tuscia48, ilmessaggero).

Inni natomiast bardzo pozytywnie wypowiadali się o urodzie pozującej modelki:

MAMMA mia Niesamowicie piękna (supercambiasso, gazzetta).

$\mathrm{Na}$ angielskim forum zdecydowanie przeważały głosy krytyczne wobec upubliczniania zdjęć nacechowanych seksualnie (tłumaczenie - S.S.): 
Robienie takich rzeczy jest sięgnięciem dna (Stuart).

Jaki normalny człowiek to robi? Ma obsesję na swoim punkcie (Geordie).

Absolutnie złe. Zero klasy!!!! (KiwiWendy).

Wielu internautów stało na stanowisku, że osoba o dużym dorobku artystycznym nie powinna sięgać po takie sposoby utrwalania obecności w mediach:

Nie Mariah nie! Jej głos wystarczy, po co robić coś takiego? Nie ma potrzeby, aby konkurować z Kim Kardashian [...] Wciąż pamiętam, jak cudowny miała głos i jak świetnie go używała [...], po co to niszczyć! (sandylove898).

[...] tego rodzaju rzeczy są dla ludzi takich jak Miley Cyrus [...] (Sheila Nistor).

Analiza wypowiedzi na wybranych forach internetowych wykazuje, że w każdym $\mathrm{z}$ trzech badanych państw przeważały głosy krytyczne wobec eksponowania ciała w mediach. Zdecydowanie najmniej przychylni temu zjawisku byli Anglicy. Jedynie na polskich portalach pojawiały się wpisy podejmujące aspekty religijne. Polscy internauci używali najbardziej pejoratywnych określeń odnośnie do osób publikujących nacechowane seksualnie fotografie swego ciała; jednocześnie największej krytyce poddawano osoby nieakceptujące tego zjawiska.

Wydawać by się mogło, że na polskich forach - ze względu na to, że Polska jest najbardziej konserwatywnym krajem spośród badanych — będzie największy odsetek opinii krytycznych wobec eksponowania zseksualizowanego ciała. Spora popularność Joanny Kuchty (choć obserwujący jej profil na Instagramie nie pochodzą wyłącznie z Polski) oraz przeanalizowane posty na forach internetowych wskazująjednak na coś przeciwnego. Przyczyny tego, jak sądzę, można upatrywaćw tym, że w Polsce później niż w państwach zachodnich pojawiło się zjawisko seksualizacji kultury (np. poprzez reklamy o podtekście erotycznym) i nie nastąpiło jeszcze bardzo silne znużenie nadmiarem takich treści. Za tezą przemawiałoby to, że w polskich wypowiedziach całkowicie incydentalnie pojawiało się określenie "nudne” (i jego synonimy) wobec powszechności upubliczniania zdjęć obnażonego ciała, podczas gdy na forach włoskich i angielskich tych zwrotów było znacznie więcej.

Hiperseksualność zachodniej kultury paradoksalnie sprawiła, że wiele osób ma coraz bardziej powściągliwy stosunek do eksponowania seksualności. Aleksandra Herman mówi: „Nagość kojarzy się nam już niemal wyłącznie z seksem, dlatego wiele osób publicznie dystansuje się od niej" ${ }^{24}$.Z kolei Suzy Menkes, dziennikarka i krytyk mody, odnotowuje: „Dzisiaj zakrywanie się wydaje się o wiele bardziej nowoczesne i seksowne niż obnażanie się"25.

Herman słusznie akcentuje zwrot „kojarzyć się” w korelacji nagość - seks, ponieważ nagie ciało w żaden sposób nie warunkuje ciała rozerotyzowanego. W mediach

24 M. Rębała, Odsłaniamy się coraz mniej, http://wyborcza.pl/magazyn/1,124059,16554515,Od slaniamy_sie_coraz_mniej.html (dostęp: 20.11.2016).

25 Ibidem. 
społecznościowych użytkownicy publikują także wiele zdjęć nagiego czy półnagiego ciała, które nie ma seksualnych konotacji.

$\mathrm{Na}$ Instagramie użytkowniczka posługująca się nickiem Nude Yoga Girl umieszcza na swoim profilu zdjęcia, na których nago ćwiczy jogę (intymne części ciała pozostają niewidoczne). Pozostaje anonimowa - na fotografiach nie widać rysów twarzy. Joginka przekonuje, że chce promować akceptację własnego ciała: „Bo wszyscy jesteśmy piękni, dokładnie tacy, jak jesteśmy" ${ }^{\prime 2}$. Podkreśla też, że chce, aby nagość była naturalna, bez erotycznego podtekstu.

Magdalena Wosińska, polska fotografka mieszkająca wStanach Zjednoczonych, zamieszcza na Instagramie (wydaje też albumy fotograficzne) swoje nagie zdjęcia na tle różnych krajobrazów, które zrobiono w czasie jej podróży po całym świecie. Wosińska podkreśla, że w tych fotografiach nie chodzi o epatowanie nagością:

Dla mnie nie ma to nic wspólnego ze zwracaniem na siebie uwagi. I z faktem, że seks się sprzedaje - bo gdyby taki był zamiar, tworzyłabym wulgarne i jak najbardziej szokujące fotografie. Wierzę po prostu w tworzenie czegoś ponadczasowego. A przy ukazywaniu nagości możesz osiągnąć taki efekt, przyjmując prostą i spokojną pozę na tle pięknego krajobrazu ${ }^{27}$.

O ponadczasowości nagiego ciała mówi także w innym wywiadzie: „Gdy zakładasz ubranie, wpasowujesz się w jakąś epokę. A ja chcę, żeby moje zdjęcia były całkowicie ponadczasowe"28. Wosińska deklaruje, że przez fotografie chce przyczynić się do propagowania akceptacji własnego ciała, niewstydzenia się nagości będącej czymś naturalnym. Uwiecznione w obiektywie kompozycje, tak jak u Nude Yoga Girl, cechuje artyzm, nie można tu mówić o zseksualizowanym ciele.

Wiele kobiet po urodzeniu dziecka zamieszcza w mediach społecznościowych zdjęcia, na których pokazują, jak szybko schudły, jak prędko ich ciała wróciły do stanu sprzed ciąży. Inne z kolei nie wstydzą się pokazać ciała zmienionego przez poród. Jedną z takich kobiet jest amerykańska blogerka Januery Harshe, która na swoim profilu na Instagramie pierwsze takie zdjęcie podpisała: „Kobiety muszą pokochać swoje poporodowe ciała"29. Australijka Olivia White fotografie swego poporodowego ciała podpisuje między innymi tak:

${ }^{26}$ Tak ćwiczy joge naga dziewczyna, http://kobieta.gazeta.pl/kobieta/1,107881,19837803,tak-cwiczy-joge-naga-dziewczyna-zdjecia.html (dostęp: 13.12.2016).

27 S. Raphael, Wkroczcie do pełnego nagości świata jak ze snu Magdaleny Wosińskiej, https://i-d. vice.com/pl/article/wkroczcie-do-pelnego-nagosci-swiata-jak-ze-snu-magdaleny-wosinskiej (dostęp: 25.11.2016).

${ }^{28}$ M. Nowak, Urodzona w Polsce amerykańska fotografka udowadnia, że nagość nie musi być wulgarna, http://polki.pl/magazyn/o-tym-sie-mowi,magdalena-wosinska-nagie-autoportrety,10419804, artykul.html (dostęp: 25.11.2016).

${ }^{29}$ Zwykłe kobiety pokazuja swoje ciało po porodzie!, http://www.radiozet.pl/Rozrywka/O-tymsie-mowi/Kobiety-wrzucaja-na-Instagrama-zdjecia-swoich-cial-po-porodzie-00004364 (dostęp: 28.11.2016). 
Pulchna twarz, oklapnięte, nabrzmiałe od mleka piersi, rozdęte biodra i brzuch w rozstępach... To jest moja pociążowa rzeczywistość. [...] Te obwisłe piersi wykarmiły moje dzieci. Dzięki nim wyrosły duże i silne. Te biodra i obwisły brzuch były domem dla moich dzieci przez 9 miesięcy ${ }^{30}$.

Zewsząd zalewają mnie zdjęcia fitmam i modelek, które pokazują swoje perfekcyjne ciała po ciąży (wyglądają, jakby nigdy w niej nie były). Moje zdjęcia są po to, żeby pokazać różnorodność i uświadomić, że taka rzeczywistość nie dotyczy każdej z nas ${ }^{31}$.

Odsuńmy od siebie tę gonitwę, na jakiś czas. Cieszmy się macierzyństwem, bez zbędnej presji, chęci szybkiej zmiany wyglądu własnego ciała, robienia z nim czegokolwiek [...] Najważniejsze teraz, że masz szczęśliwe, zdrowe dziecko ${ }^{32}$.

\section{Zakończenie}

Dzięki postępowi technologicznemu człowiek w krótkim czasie może zrobić wiele zdjęć i udostępnić je setkom, tysiącom, milionom osób. Część fotografii przedstawia nagie czy półnagie ciało. Niekiedy przyświeca temu określona idea, $\mathrm{w}$ innych przypadkach jest to chęć bycia widzianym, stanowiąca dla wiele osób podstawę tożsamości.

Nagość nie jest tożsama z seksualnością. Zdjęcia poporodowe, karmienie dziecka piersią, profilaktyka nowotworowa - to tylko kilka egzemplifikacji prezentacji nagiego ciała nienacechowanego seksualnie.

Z kolei eksponowanie rozerotyzowanego ciała w mediach społecznościowych służy zdobywaniu bądź utrzymywaniu popularności, ale wiele jednostek traktuje to także jako czynność wręcz rutynową. Ten swoisty ekshibicjonizm dotyczy zarówno celebrytów, jak i ludzi szerzej nieznanych. Wiele osób jednak nie akceptuje tych zjawisk i nie bierze w nich udziału. Piosenkarka Adele słusznie mówi: „Wykorzystywanie swojej seksualności i wyglądu nie jest dobrym pomysłem. To nie jest ciekawe"33.

30 „Oklapnięte, nabrzmiałe od mleka piersi, rozdęte biodra i brzuch w rozstępach”. Odważyła się na naga sesję po porodzie, http://www.edziecko.pl/edziecko/7,79308,20815049,oklapniete-i-nabrzmiale-od-mleka-piersi-rozdete-biodra-i-brzuch.html (dostęp: 28.11.2016).

31 Ibidem.

32 A. Jaros, Blogerka tym zdjęciem mówi: „Dość presji idealnego ciała tuż po porodzie. Mamy, odpuśćcie", http://mamadu.pl/128491,blogerka-tym-zdjeciem-mowi-dosc-presji-idealnego-ciala-tuz-po-porodzie-mamy-odpusccie (dostęp: 29.11.2016).

${ }_{33}$ Adele krytykuje gwiazdy za epatowanie nagością, http://www.gala.pl/artykul/adele-krytykuje-gwiazdy-za-epatowanie-nagoscia (dostęp: 30.11.2016). 


\section{Bibliografia}

Absurdalne przepisy Instagrama zabraniają pokazywania kobiecych sutków, http://kobieta.gazeta.pl/ kobieta/1,107881,18315825,nipple.html.

Adele krytykuje gwiazdy za epatowanie nagością, http://www.gala.pl/artykul/adele-krytykuje-gwiazdy-za-epatowanie-nagoscia.

Bauman Z., 44 listy ze świata płynnej nowoczesności, Kraków 2011.

Blogerki plus size walcza $z$ Instagramem. Serwis zablokowat hasztag \#curvy, http://www.tvp.info/ 20921619/blogerki-plus-size-walcza-z-instagramem-serwis-zablokowal-hashtag-curvy.

Burszta W., String umysłowy i jego powaby, „Kultura Popularna” 2002, nr 2.

Gąsior M., „Uwolnić sutek!” - amerykańska aktorka walczy z cenzura nagiego ciała na Facebooku, http://natemat.pl/88303, uwolnic-sutek-amerykanska-aktorka-walczy-z-cenzura-nagiego-ciala-na-facebooku.

https://napoleoncat.com/analytics/instagram

https://pl-pl.facebook.com/help/instagram/478745558852511

http://wsjp.pl/index.php?id_hasla=33625\&ind=0\&w_szukaj=eksponowa\%C4\%87+

Janczewski M., CeWEBryci - sława w sieci, Kraków 2011.

Jaros A., Blogerka tym zdjęciem mówi: „Dość presji idealnego ciała tuż po porodzie. Mamy, odpuśćcie”, http://mamadu.pl/128491,blogerka-tym-zdjeciem-mowi-dosc-presji-idealnego-ciala-tuz-po-porodzie-mamy-odpusccie.

Kampania przeciw nowotworowi piersi kpi z zasad nagości na Facebooku i Instagramie, http://www. wirtualnemedia.pl/artykul/kampania-przeciw-nowotworowi-piersi-kpi-z-zasad-nagosci-na-facebooku-i-instagramie-wideo\#.

Kędra N., Joanna Kuchta: ta 19-letnia Polka ma więcej fanów na Instagramie niż Anja Rubik! Modelka przyszłości? [FENOMEN], http://kobieta.gazeta.pl/follow/1,153346,18516294,joanna-kuchta-modelka-instagram.html.

Krajewski M., Intymność w przestrzeniach publicznych: powtórzenie, dyseminacja i rozproszenie, [w:] Formy zamieszkiwania. Publiczne i prywatne przestrzenie miasta, red. P. Wołyński, Poznań 2010.

Krzemińska R., Joanna Kuchta - insta, wirtualne życie i feminizm, http://loungemagazyn.pl/insta-wirtualne-zycie-i-feminizm/.

Mazurek-Lipka O., Sukces typu instant - tożsamość celebryty i celebutantki, „Kultura - Społeczeństwo - Edukacja" 2013, nr 2.

McNair B., Seks, demokratyzacja pożądania i media, czyli kultura obnażania, przeł. E. Klekot, Warszawa 2004.

Melosik Z., Facebook i społeczne konstrukcje narcyzmu (o tożsamości zamkniętej w celi wizerunku), „Studia Edukacyjne” 2013, nr 26.

Nowak M., Urodzona w Polsce amerykańska fotografka udowadnia, że nagość nie musi być wulgarna, http://polki.pl/magazyn/o-tym-sie-mowi,magdalena-wosinska-nagie-autoportrety,10419804, artykul.html.

Nowe wyzwanie: zasłoń się jednym palcem!, http://kobieta.interia.pl/zycie-i-styl/news-nowe-wyzwanie-zaslon-sie-jednym-palcem,nId,2315667.

„Oklapnięte, nabrzmiałe od mleka piersi, rozdęte biodra i brzuch w rozstępach”. Odważyła się na naga sesje po porodzie, http://www.edziecko.pl/edziecko/7,79308,20815049,oklapniete-i-nabrzmiale-od-mleka-piersi-rozdete-biodra-i-brzuch.html.

Raphael S., Wkroczcie do pelnego nagości świata jak ze snu Magdaleny Wosińskiej, https://i-d.vice. $\mathrm{com} / \mathrm{pl} /$ article/wkroczcie-do-pelnego-nagosci-swiata-jak-ze-snu-magdaleny-wosinskiej.

Rębała M., Odsłaniamy się coraz mniej, http://wyborcza.pl/magazyn/1,124059,16554515,Odslania my_sie_coraz_mniej.html.

„Sutek zostat czasowo uciszony, ale powróci. O tak, powróci”. Pomógł lakier do włosów, http:// www.tvn24.pl/ciekawostki-michalki,5/zdjecie-z-sutkiem-chrissy-teigen-zniknelo-z-instagrama,556417.html. 
Tak ćwiczy jogę naga dziewczyna, http://kobieta.gazeta.pl/kobieta/1,107881,19837803,tak-cwiczy-joge-naga-dziewczyna-zdjecia.html.

Usunięta $z$ Instagrama za "rozbierane” zdjęcia, http://kobieta.wp.pl/usunieta-z-instagrama-za-rozbierane-zdjecia-5982735142450305a.

Zawadzka A., Masz zbędne kilogramy albo boczki? Uważaj, bo jeszcze usuna ci konto na Instagramie, http://natemat.pl/110277,masz-zbedne-kilogramy-albo-boczki-uwazaj-bo-jeszcze-usuna-ci-konto-instagramie.

Zwykłe kobiety pokazuja swoje ciało po porodzie!, http://www.radiozet.pl/Rozrywka/O-tym-sie-mowi/Kobiety-wrzucaja-na-Instagrama-zdjecia-swoich-cial-po-porodzie-00004364.

\section{Social media as a space for displaying the body}

\section{Summary}

In this text, I analyze various aspects of exhibiting the body in social media (focusing on Instagram and Facebook). I examine the rules of insertion the images depicting naked and halfnaked body, and social actions contesting these regulations. I also examine the level of social approval of publishing photos marked by sexual abuse. Moreover, I show some examples of displaying the naked body having no sexual connotation. 